\title{
The Contact Hypothesis Revised: DoM in the South Slavic Periphery
}

\author{
Eleni Bužarovska \\ Professor of Linguistics, Faculty of Philology, Ss. Cyril and Methodius \\ University, Skopje, Republic of North Macedonia \\ elenibuzarovska@t.mk
}

\begin{abstract}
The aim of this paper is to provide an explanation of the emergence of DOM in peripheral Macedonian dialects through a reevaluation of the contact hypothesis. The southern and south-western dialects in the contact zones with Greek and Aromanian use a dative-based pattern to mark specific, predominantly human and animate referents. However, the contact hypothesis cannot fully explain the origin of Dом in the southernmost dialects because it overlooks the wider interlingual context within which this change occurred. Relying on the analysis of the examples from the oldest sources with DOM, the author argues in favor of a multifactorial explanation of its origin: contact obscured the case marking functions of clitics and provided an analytic direct object pattern. The introduction of $n a$-marking on direct objects satisfied both the semantic and pragmatic requirements of a successful message by discriminating between the syntactic functions and discourse prominence of the object participant.
\end{abstract}

\section{Keywords}

Balkan Sprachbund - clitics - direct object - case marking - dative pattern - discourse prominence

Differential object marking (henceforth DOM) is a widespread crosslinguistic strategy in which prominent objects ranking high on the animacy hierarchy 
receive casemarking, while low ranking objects remain unmarked. DOM is attested in at least $25^{\circ}$ genetically different languages such as Spanish, Turkish, Persian, Hindi, Hebrew, etc. (Bossong, 1984). ${ }^{1}$ In Romance languages DOM is dative-based; thus Spanish employs the prepositional marker $a$ and clitic doubling (von Heusinger and Kaiser, 2003), whereas the Romanian marker pe is obligatory for definite direct objects and optional with indefinite but discourse prominent objects (Chiriacescu and von Heusinger, 2010). ${ }^{2}$ DOM in Aromanian dialects seems to be attested sporadically across the Balkan area: in the southwestern dialects of Ohrid and in the dialect in Krania (Thessaly, Greece). Standard Balkan Slavic languages do not have DOM, except for some dialects where it has the form of the grammaticalized preposition $n a$.

Languages differ as to what motivates overt morphological case-marking on their direct objects. The reasons are predominantly sought in pragmaticsemantic features of these marked objects (definiteness, animacy, affectedness), but the role of their discourse features (prominence and topicality) has also been recognized. ${ }^{3}$ In fact, the interplay of several hierachies influences accusative marking of patient-like objects: "P-marking is the more likely, the higher the $\mathrm{P}$ is on the animacy, definiteness and person scales" (Haspelmath, 2007: 83), which roughly correspond to the prominence scale (Aissen, 2003). ${ }^{4}$ Prominence involves "the centrality of an entity in the discourse" or "the readiness with which an entity presents itself to the speaker as a topic of conversation" (de Swart, 2007:138).

The phenomenon of Dом in Macedonian dialects was explored mostly by Koneski (1986) and Topolinjska (1995), but also discussed by other authors (Cyxun, 1981; Tošev, 1970; Vidoeski, 1998; Markoviḱ, 2007; Bužarovska, 2001 among others). Most of the scholars investigating this specific construction in

1 DOM in Spanish has been extensively investigated (Aissen, 2003; Leonetti, 2004; von Heusinger and Kaiser, 2003, 2007, von Heusinger 2008 among others). Typological variation in systems of differential argument marking (DAM) are discussed in Witzlack-Makarevich and Seržant (2018).

2 The marker $a$ also occurs in ditransitive constructions (von Heusinger and Kaiser, 2011). Hill (2013) argues that $p e$ in Romanian is not case assigning preposition but a discourse marker.

3 Bossong (1984:6) distinguishes animacy and referential differentiation depending on whether inherent or pragmatic (referential) features of the direct object referent motivate the use of Dом. In his view, referential differentiation is predominant among the languages with DOM, although a number of authors consider animacy to be the determining parameter (de Swart, 2007; de Swart and de Hoop, 2007; Kitillä, 2006), or the combination of both ("harmonic alignement" in Aissen, 2003). Other authors attribute primacy to topicality (EscandellVidal, 2009; Dalrymple and Nikolaeva, 2011; Hill, 2013).

4 It is comprised of animacy scale and definiteness scale. Animacy scale: Human $>$ Animate $>$ Inanimate; Definiteness scale: Personal pronoun $>$ Proper noun $>$ Definite NP $>$ Indefinite specific NP > Non-specific NP. Compare Aissen's (2003: 437) view that prominence is established by two hierarchies: definiteness and animacy. 
Macedonian and Bulgarian dialects do not relate it to DOM and the literature on Doм (Koneski, 1986; Topolinjska, 1995; Asenova and Aleksova, 2008). The first use of this term in Balkan Slavic scholarship is in Adamou (2006: 64; 2009).

The DOM strategy in Balkan Slavic dialects is based on the analytic dative pattern. The allative preposition $\mathrm{na}$ 'on' regularly encodes a dative relation, but in southern and south-western Macedonian dialects it occurs in direct dependency constructions. In these dialects, the use of $n a$ with direct objects is governed by semantic and pragmatic considerations because only specific, predominantly animate objects receive differential marking. To prove this hypothesis we analyze the properties of the examples with DOM in two $19^{\text {th }}$ century texts written in colloquial dialects. The analysis shows that DOM in Macedonian dialects is sensitive to the pragmatic-semantic features with specificity/definiteness being the necessary precondition. Specific referents are "uniquely identifiable" because "[ $t$ ]he addressee can identify the speaker's intended referent on the basis of the nominal alone" (Gundel et al., 1993: 217). Although the use of the marker $n a$ in this respect is similar to the Spanish $a$, $n a$-marking has a different sociolinguistic status. DOM in Macedonian is a marginal feature of peripheral dialects, while in Romance languages it belongs to the standard.

During the common Byzantine and Ottoman past, the languages of the Balkans underwent convergent development ${ }^{5}$ which brought about significant structural changes shared by the members of the Balkan Sprachbund. These languages, including Balkan Slavic languages, typologically are characterized by explicit analytism: they overtly mark grammatical relations with free morphemes-prepositions, (p)articles, and auxiliaries (Lindstedt, 2014: 169). Macedonian south-west dialects belong to the most balkanized core of the Balkan Sprachbund (Lindstedt, 2000: 234), and therefore constitute convergence areas within the Balkan Sprachbund. Joseph (2010) argues that Balkan Sprachbund should be viewed as a unity of several smaller convergence areas where intense, intimate and mutual multilinguism took place. Bilingual speakers in these multilingual communities must have resorted to the constant code switching as a result of their daily interactions, contributing to greater structural isomorphism at sentence level between the contact languages. It can be argued that such striking similarity of sentence structure in Balkan languages has resulted in a high degree of mutual translatability, which makes it possible

5 The role of Balkan Slavic in the convergence process was that it "accelerated the expansion of the contact-induced changes and strengthened typological links between particular Balkan languages" (Topolińska, 2010: 56 ). 
to employ a morph-for-morph translation of a sentence (cf. Gumperz and Wilson, 1971). ${ }^{6}$

In Macedonian, the tendency for explicit analytic marking of semantic and syntactic relations is most pronounced (Lindstedt, 2019). The presence of DOM in peripheral Macedonian dialects may not have been an exception to this tendency. As suggested by several authors, Dом in these dialects appeared as a result of colloquial contact with two languages: Aromanian and Greek. Aromanian, a ром language, is considered to have triggered Dом in the Ohrid dialect (Markovik, 2007), lending the construction of the type I vizdui pi Taki 'I saw (dom) Taki'. Following Koneski (1986), dialectologists describing southern and south-western Macedonian dialects attribute the presence of Dom to the contact with Aromanian (Vidoeski, 1998; Peev, 1987; Karanfilovski, 20o9; Mladenov, 1993; Labroska, 2003; Markovik, 2007; Sobolev, 2008), although none of these authors offers an interpretation of DOM based on a distributional analysis.

With regard to the appearance of Dом in the southernmost Macedonian dialects, Topolinjska (1995) suggests Greek influence but links it to the internal changes in their nominal systems. On this view, Greek, a language without ром, ${ }^{7}$ indirectly influenced the southernmost Macedonian dialects in replicating the northern Greek dative-accusative pattern (Bužarovska, 2001).

The following examples illustrate the use of DOM: in Ohrid dialect (1) and in the southernmost dialect (2).

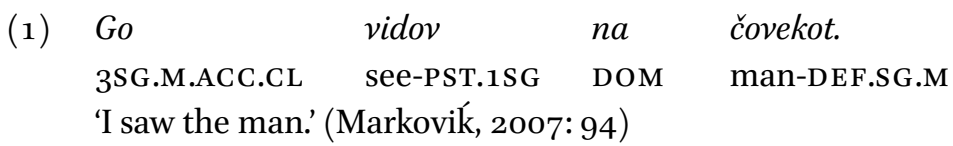

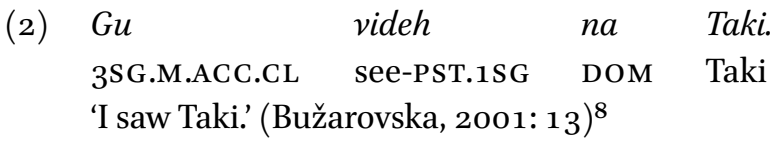

6 Gumperz and Wilson (1971) emphasize the importance of translatability between languages/ dialects in contact, i.e. the ability of bilingual speakers to translate a sentence word for word because of a single syntactic surface structure, a result of the codes bilinguals use in code switching situations. These conclusions were drawn from the analysis of bilingual texts of three dialects (two of which are genetically unrelated) spoken in an Indian multilingual village (Kupwar) with "an extraordinary degree of translatability" between the compared sentences (ibid: 154-155).

7 Northern Greek dialects do not have Dом, but have an analytic construction for encoding both dative and accusative dependencies, which is explained in section 4.

8 All dialectal examples are rendered phonetically, as they were written down in dialectal materials. This utterance was used by older informants who spoke the southern dialect of Yanitsa (Enidže-Vardar/Pazar) in Greece. 
However, the contact with Aromanian ${ }^{9}$ has not been fully explored nor recognized as an external motivating factor. Some researches challenge this view (Asenova and Aleksova, 2008; Adamou, 2009), while some do not rank contact as a decisive factor (Topolinjska, 1995). Doubts in contact hypothesis are substantiated by the fact that DOM is absent in some Macedonian dialects (for instance Bitola or Kruševo) in spite of lengthy and close contact between Macedonian and Aromanian population in these regions. The reverse scenario is also true: in the second half of the $19^{\text {th }}$ century Dом was widespread in the southernmost dialect near Langada Lake (north and north-east of Thessaloniki, Greece) even though no Aromanian presence was documented in that area (Adamou, 2009).

With respect to the source for DOM in the Ohrid dialect, the contact hypothesis of ром cannot be dismissed, but contact explanations should be elaborated with more scrutiny. Other factors may have contributed to the irregular use of DOM in this region: internal factors activated by the need for transparency in a multilingual environment, as well as sociolinguistic factors pertaining to the divide between urban and rural speech. Thus, speakers of Ohrid and Struga, many of whom are of Aromanian descent, use $n a$-direct objects in colloquial language, ${ }^{10}$ whereas this feature is missing in the villages near these towns (Vidoeski, 1998).

The hypothesis about the Greek influence in the appearance of ром in southernmost Macedonian dialects (spoken in Dojran and in some northern regions in Greece) ${ }^{11}$ also needs revision. DOM in these dialects displays two properties: optionality in use and uneven interdialectal distribution. The long contact in the past between southernmost Slavic dialects and northern Greek dialects triggered the appearance of Dом, but this innovation occurred because of the demise of the inherited Slavic case system and its subsequent analytic restructuring (Topolinjska, 1995; Cyxun, 1981).

What should be taken into consideration in the emergence of this dialectal DOM is the Balkan Sprachbund context within which it occurred. Prolonged language contact enhanced the need for successful communication

9 Nowadays, DOM marking is attested in the Aromanian dialect of Ohrid and Struga, where the prepositional marker pi regularly marks human objects. But in the dialect of Krania (Thessaly, Greece), the use of pra/pri seems to be an optional but preferred strategy with specified human referents: beulu nu-l kunusku prā elinopul, prā fičorlu 'The bey did not recognize the Greek boy, the little boy' (Sobolev, 2008: 44).

10 The use of $n a$-marked direct objects in the speech of Ohrid and Struga schoolchildren is described in Bužarovska (2017).

11 It should be noted that the materials from the minority dialects in Greece to a great extent reflect a past situation because the younger generation is increasingly becoming monolingual due to education in Greek medium. 
in a multilingual environment, including the need for a more transparent marking of the semantic and pragmatic meanings of conveyed messages. The internal factors, such as principles of economy and iconicity, have led to the structural simplification of the case system and subsequent grammaticalization of the adpositional dative marker. By marking the second human discourse participant with the same marker in direct dependency relations, the users of Dом generalize the analytic case marking and simultaneously upgrade the transparency and informativeness of the message. The grammatical simplification in Balkan languages was paired up with pragmatic enrichment of verbal messages: marking the beginning of the communication, attention signals, emphasis on semantically important element of communication, introduction of rheme with clitics, etc. (Civjan, 1979: 284).

The paper adopts an interfaced syntactic-pragmatic approach in the interpretation of the diachronic Dом examples. To explain the principles governing the rise of Dом in these dialects, we draw on the theories of case marking functions (Siewierska and Bakker, 2008) and discourse prominence (Dalrymple and Nikolaeva, 2011; Gundel et al., 1993). As indirect objects prototypically refer to individuated human recipients, the spread of Dom was directed along three dimensions: definiteness, humanness and important discourse status, subsumed here under the term discourse prominence. Prominence (or topic worthiness) depends on semantic parameters conditioned on animacy ${ }^{12}$ and definiteness scales. It correlates with topicality, a pragmatic feature of the information structure that expresses the informational status of a referent and "depends on the speaker's construal of the situation within the given communicative context" (Dalrymple and Nikolaeva, 2011: $5^{2}$ ). Although specific human referents are presuppositional, they are topical when they carry the communicative focus of the utterance.

The above discussion suggests that DOM in Macedonian dialects resulted from the interplay of external and internal factors. Assigning a background role to contact, the use of DOM in southernmost Macedonian dialects can be explained by invoking principles of iconicity and economy which work together with semantic and information structure principles. The goal of this paper is to prove that Dом in the southernmost dialects was caused by the communicative necessity of speakers to clarify their message by overtly marking the second human participant and thus ascribe him/her a prominent discourse status.

12 Malchukov (2008: 204) notes that some grammatical categories, like number and agreement, are sensitive to prominence and display animacy effects. Related to animacy and discourse prominence is the speaker's empathy. 
The paper is organized as follows: the next section clarifies the theoretical framework applied in the analysis of dialectal Dom examples. Section 3 offers a summary of the chronological attestation of DOM in Macedonian dialects; the subsequent section presents the results of the diachronic analysis of DOM examples from the oldest written sources; several hypotheses about the emergence of DOM in these dialects are offered in section 5 . The conclusion reevaluates the theoretical assumptions in the light of the findings from the presented diachronic analysis.

\section{Case Relations and Case-marking}

It is well known that morphological case has been lost in Balkan Slavic (except in personal pronouns), a change that has created certain difficulties in discriminating between the agent and the patient. Their syntactic roles in a transitive clause are distinguished by case marking, word order and agreement. Inherent and referential features are marked on arguments, but the referring specified arguments in object positions are analytically casemarked by clitisized preverbal short pronouns. Since Dом in Macedonian dialects co-occurs with clitic doubling (obligatory in south-western dialects) it is important to understand the role of clitics in disambiguating objects from subjects. In finite transitive sentences the dependency of definite nominals is signaled by accusative or dative clitics. These anticipating replicas, necessarily repeat the categorical information of person and number (gender in 3p.sing) of the object referent; in fact, clitic doubling was prompted by the loss of case (Ilievski, 1988: 172). Being the only marker of case, the clitic performs several functions: via case marking it differentiates the object from the subject and simultaneously indexes the second participant as affected.

Indirect dependency employs an adpositional strategy: the grammaticalized allative preposition na precedes a non-specific or specific nominal or an accusative strong pronoun. ${ }^{13}$ Recipient arguments are additionally indicated by obligatory dative proclitics corresponding to the categorical features of the recipient. This means that indirect dependency of definite objects is marked twice: by $n a$ and by the dative clitic, the latter additionally encodes agreement.

13 Except for the synthetic dative strong pronouns nejze (f) 'to her', nemu (m) 'to him' and nam (pl) 'to us', which in spoken language are replaced by the analytic $n a+$ accusative form (casus generalis), producing forms na nea, na nego, na nas, e.g. Mu rekov nemu/na nego 'I told him'. The earliest example of the preposition $n a$ in dative function $(n a+$ accusative pronoun) dates back to the $13^{\text {th }}$ century Bologna Psalter (Koneski, 1967: 166). 
As explained above, DOM in Macedonian regions is based on the dative pattern. In Dом dialects, transitive and ditransitive constructions, especially those involving speech verbs, have overlapped and only the casemarked clitic (and the verb's meaning) indicates the difference. Ambiguity may arise in direct speech with third person participants, particularly with a rhematic postverbal subject and an unrealized theme as in (3) and (4). Moreover, the accusative clitic may be missing: in some southern and eastern dialects, similarly to other Balkan languages (Bulgarian, Greek), clitic doubling is optional because it has not been fully grammaticalized.

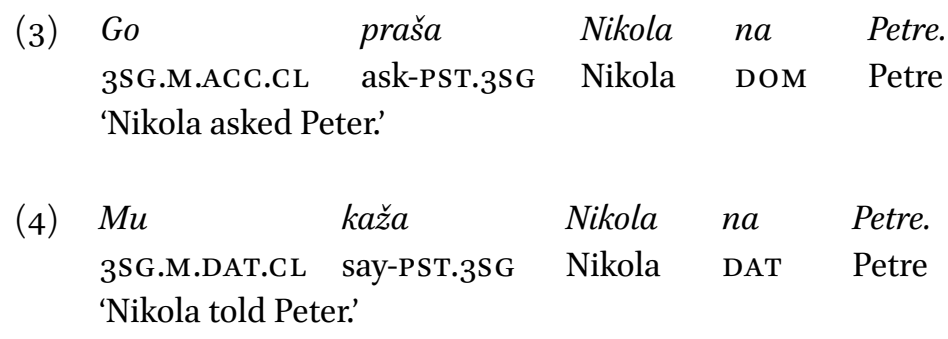

Why then would speakers introduce $n a$ whereby erasing the formal distinctions between the two constructions? It seems that $n a$ signals objecthood, that the second human participant (patient or theme) is affected by the activity of the animate agent.

A closer look into the functions of case marking is necessary to understand their role in the use of Dом. As accepted in the literature (Siewierska and Bakker, 2008), case marking on the arguments performs two functions: discriminating and indexing. In a prototypical transitive pattern the former function distinguishes the subject (agent) from the object (patient), while the latter is used "to highlight the semantic closeness of arguments to the prototype of a given role" (Kittilä, 2011: 5). A prototypical patient is an affected (and indefinite) inanimate entity (Comrie, 1989: 128) realized by an accusative noun phrase, though it has been argued that animate patients are more affected than inanimate ones (cf. Næss, 2004).

It is difficult to tease apart these two functions and determine which one played a decisive role in the rise of Dом in Macedonian dialects. A number of authors (de Swart, 2007; Malchukov, 2008) maintain that marking animate patients is consistent with both syntactic and discourse functions: DOM prevents confusion with the subject, and also signals that the animate and specific patient is prominent in discourse. Animacy is more clearly related to the differentiating function of Dом because a marked animate object canot be confused with an animate subject. On the markedness hypothesis, a patient animate 
object diverges from the prototype of a transitive clause (Comrie, 1989; Aissen, 2003). ${ }^{14}$ This implies consistent obligatory marking of all human direct objects, but in Macedonian dialects Dом is predominantly preferential. It seems that the introduction of $n a$ has considerably eased the distinguishability between the two human participants in a clause, especially in southern dialects where clitic doubling is optional.

The second function pertains to the relation of affectedness and prominence in animate patients. Affectedness, as a feature of the discriminatory function of casemarking, is also implied in the indexing fuction: animate individuated patients are perceived as affected because it is more important to mark affectedness on animate participants. In highly transitive situations animacy and referentiality are responsible for the object's 'individuation', i.e. prominence (Hopper and Thompson, 1980). Malchukov (2008: 211) argues for a correlation between affectedness and degree of prominence, concluding that under the indexing perspective animacy effects are induced indirectly "through correlations between animacy features and role-related characteristics of arguments".

It follows from this discussion that the animacy parameter in casemarking is directly related to the differentiating function, and indirectly to the indexing one because human patients are more salient in discourse and thus perceived to be affected. It is possible that the former function had initially triggered the use of the accusative $n a$, but during the grammaticalization of this $n a-$ pattern the latter (indexing) function prevailed, regulating its use in accordance with the speaker's perception of the degree of the object's prominence and topicality.

The humanness (implying prominence) of the prototypical recipient in the indirect object position rendered by $n a$ is associated with the human and prominent unprototypical patient in the direct object position. Subsequently, na-marking of human patients has spread onto animate and even inanimate patients deemed to be topic worthy participants. Since human recipients, being inherently more topical than theme arguments (Kittilä, 2006; Haspelmath, 2007), are marked by $n a$ in ditransitive constructions, by analogy $n a$ was extended to human (also topical) patients in transitive constructions. Thus the syntactic marking on recipients was replicated on human patients with a high discourse status. It seems, therefore, that both animacy (induced by the discriminating function) and discourse prominence (induced by indexing) motivate the use of DOM in southern dialects.

14 Typically, patients are inanimate and indefinite in prototypical transitive situations (Comrie, 1989: 128). 
It can be further hypothesized that in contact with a non-Slavic language(s), the two functions compete, which explains the non-obligatory use of Dом in southern Macedonian dialects and its extension to inanimate referents.

\section{Distribution and Diachrony of DoM}

It is important to underline that DOM in Macedonian dialects is not evenly distributed both areally and historically. Today D ом is attested in the southern and southwest region of the Republic of North Macedonia, but the dialects with Dом in the border regions in Greece are predominantly spoken by older speakers due to the limited intergenerational transmission of their mother tongue. Na-marked direct objects were attested in a wider belt from Korcë in south-east Albania, through Kastoria and Thessaloniki to Serres in northern Greece (Vidoeski, 1998: 115). Nowadays this feature is present in the southern dialect of Doiran and south-western dialects of Ohrid, Struga and Debar.

To prove the hypothesis that contact was an auxiliary mechanism in the spread of Dом in southernmost dialects, diachronic data from these regions were examined. The data chronologically can be divided into two parts:

(a) older materials represented by the Kulakia Gospel (Mazón and Vaillant, 1938) and by the folk tales collected by Stefan Verkovik (Penušliski, 1985) in the sixth decade of the $19^{\text {th }}$ century,

(b) newer dialectal materials collected a hundred years later (Vidoeski, 2000; Peev, 1987; Karanfilovski, 2009; Labroska, 2003 among others).

The present investigation focuses on the analysis of the examples with Dом in the older sources, without aspiring to provide an exhaustive overview of the distribution and chronology of Dом. It is impossible to accurately trace the diachronic development of ром in these dialects because ample written evidence of spoken language is lacking. During the Byzantine and Ottoman rule, Slavic literary texts strictly followed the written tradition of Church Slavonic. ${ }^{15}$

Koneski's observations (1986) regarding the diachrony of DOM objects help shed light on the development of this phenomenon in the past. It seems that by the middle of the $19^{\text {th }}$ century DOM had already taken root in the southernmost dialects, although not earlier and not in the southwest: both the Konikovo

15 Regarding spoken language some authors (e.g., Ilievski, 1988: 166) maintain that widespread bilingualism existed between Greek and Slavic populations in contact regions. 
Gospel (Lindstedt et al., 2008; Lindstedt, 2015) ${ }^{16}$ found in the village Konikovo (nowadays Dytiko, near Yanitsa, Greece) and the Lexicon Tetraglosson, ${ }^{17}$ written at the very end of the $18^{\text {th }}$ century, do not have this construction.

Relying on diachronic evidence, Koneski (1986: 202) observes that prepositionally marked direct objects were common in the middle of the $19^{\text {th }}$ century in southernmost dialects. The earliest, and the only example (5) was found in a folk poem from Kilkis (Kukuš, a small border town in Greece) included in the Miladinov Brothers' Collection, published in 1861 in Zagreb.

$\begin{array}{llllll}\text { (5) Toga } & \text { ja } & \text { ritna } & \text { ličen } & \text { svetiGeorgi } & n a \\ \text { then } & \text { 3SG.F.ACC.CL } & \text { kick-AOR.3SG } & \text { handsome } & \text { saint George } & \text { DOM }\end{array}$

$\begin{array}{llll}\text { sura Lamja } & \text { po } & \text { kleto } & \text { srce } \\ \text { dragon-SG.F } & \text { on } & \text { cursed } & \text { heart }\end{array}$

'Then handsome saint George kicked the dragon on its cursed heart.'

A much higher number of examples with Dом is attested in the Kulakia Gospel and Verkovik's collection of folk tales. ${ }^{18}$ Both originate from the same period (1863) in neigboring regions near Thessaloniki (Greece) close to the delta of the Vardar/Axios River. These dialects were referred to by Mazón and Vaillant (1938) as the Low Vardar dialects. The Kulakia Gospel was created in Chalastra village (former Kulakia), north-west of Thessaloniki. The text in the Gospel was written in the local vernacular dialect using the Greek alphabet. Mazón and Vaillant (ibid.) published the transcribed text in Latin script incorporating an extensive linguistic analysis.

Verkovik's collection contains folk tales from several villages in northern Greece, such as Ossa (former Visoka) in the Langada region (north-east of Thessaloniki), the village Lehovo (near Florina, Greece), and the small town of Yanitsa (Enidže Vardar).

16 The Konikovo Gospel was written at the end of $18^{\text {th }}$ or beginning of $19^{\text {th }}$ century. It contains a Greek evangelarium and its Slavic translation with Greek letters. Both the Greek and the Slavic texts represent the vernacular, not the church language. For more imformation see http://www.helsinki.fi/ jslindst/268/.

17 The Lexicon Tetraglosson is a quadrilingual lexicon of Greek, Albanian, Vlach (Aromanian), and "Bulgarian" (Macedonian dialect of Ohrid) written by Daniel Moscopolites, an Aromanian priest from Moscopole. It is assumed that the Slavic version was translated from Greek by Stefan, an Ohrid priest of Aromanian descent (Nichev, 1997).

18 Koneski (1986: 202-206) relies on Mazón and Vaillant (1938) for data about the Kulakia Gospel. 
Although Koneski (1986: 202-204) claims that this "interesting innovation" is used to mark human direct objects (6), he concedes that the 'direct $n a$ object' in the Kulakia Gospel may co-occur with inanimate referents (7), but does not offer an explanation.

(6) $j a$

pitaha na

babata

3SG.F.ACC.CL

ask-PST.3PL

ром

old woman-DEF.SG.F

'They asked the old woman.'

(7) utidi

da kupa

na

zemnjata $^{19}$

go-PST.3SG

SBJV buy-PRS.3SG

DOM

land-DEF.SG.F

'He/she went to buy the land.'

The oldest texts from Florina (Lerin) and Kastoria (Kostur) region ${ }^{20}$ (to the north of the above mentioned dialects) do not have $n a$-objects except for one example (8), leading Topolinjska (1995: 93) to conclude that it "predicts a later development".

(8) $\check{S} \check{c} 0$

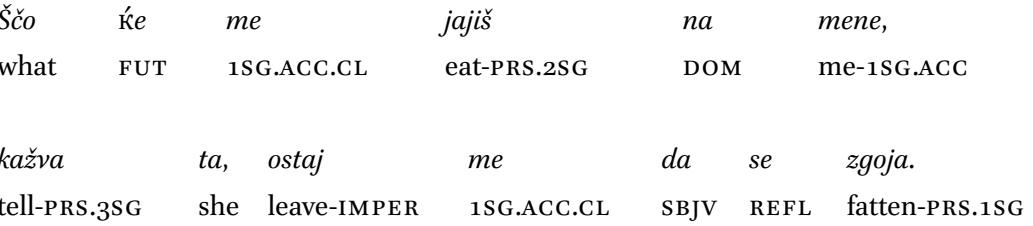

'Why do you have to eat me, says she, let me grow fat.'

At the end of the $19^{\text {th }}$ century this feature was recorded in the south-west dialect of Kastoria/Kostur (Seliščev, [1918] 1981: 185), and in the southernmost dialect of Karteres/Kiretskoj (a village in Langada region). In example (9) from that region (Cyxun, 1981: 47) $n a$ is used with the direct object pronoun in the nominative form ( $t i$ instead of the accusative tebe), a fact that betrays the detriment of the case system. In addition, its redundant use (besides the clitic $t e$ ) indicates that the human object is highly topical.

19 In the noun zemnja 'ground, earth', instead of zemja, an epenthetic n' is inserted in m'a endings following the Greek demotic use (potamnia 'rivers'). This is noted in many southslavic dialects (East Serbian) and in Romanian dialects (see Seliščev, [1918] 1981: 148).

20 Topolinjska (1995) refers to Mazón and Vaillant (1938) for older data from Florina (Lerin) and Kastoria (Kostur), small towns in Greece near the border with the Republic of North Macedonia. 
$\begin{array}{lllll}\text { (9) } & \text { ne } \quad \text { te } & \text { sakam } & n a & t i \\ \text { NEG 2SG.ACC.CL } & \text { love-PRS.1SG } & \text { DOM } & \text { you-2SG.NOM } \\ & \text { 'I don't love you.' } & & & \end{array}$

In the first half of the last century, $n a$-marking was attested in a folk tale from the village of Kolchiko/Balevac (Lagadina region, Greece) where the object referent is an animate being: fati na pčelata '(he) caught the bee' (Vidoeski, 2000:

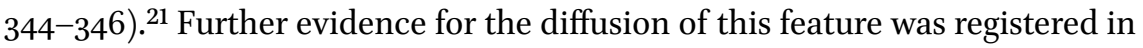
the dialects to the east (towards Serres/Ser), north (Yanitsa/Enidže Vardar and Kilkis/Kukuš) and west (Kastoria/Kostur) of this southernmost region. The dialectal materials gathered from the informants who had lived in these regions testify to an irregular use of $n a$. Thus, in the texts from the village of Paliokastron/ Kula near Serres/Ser (Labroska, 2003) half of the direct objects were unmarked. Yet, certain regularity in $n a$-object distribution can be observed in all examples provided in these sources (Karanfilovski, 2009; Peev, 1987). It seems that its occurrence was governed by discourse principles - the human and animal referents of the marked objects in these tales are topical, occupying a topicalized $(10)^{22}$ or a rhematic position (11). This is particularly evident in the use of $n a$ with the only inanimate object (12), whose referent (the envelope) is highly relevant for the ensuing turn of events in the narrative.

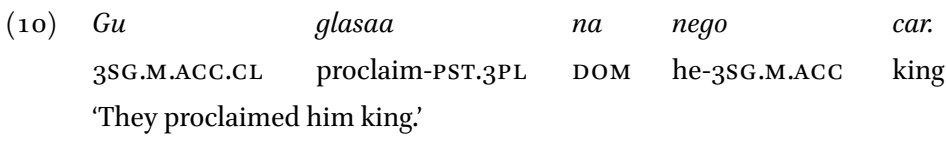

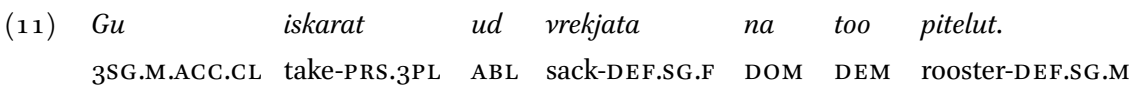
'They take that rooster out of the bag.'

$\begin{array}{llll}\text { (12) } \begin{array}{lll}\text { Vadi } \\ \text { take-PRS.3SG }\end{array} & \begin{array}{l}\text { molivo, } \\ \text { pencil-DEF.SG.M }\end{array} & \begin{array}{l}\text { isea } \\ \text { cut-PRS.3SG }\end{array} & \begin{array}{l}\text { na } \\ \text { DOM }\end{array} \\ \text { poleka poleka } & \text { go } & \text { otvoral. } \\ \text { slowly slowly } & \text { 3SG.M.ACC.CL } & \text { open-PRF.3SG.M } \\ \text { 'He took out the pencil, and cut the envelope and slowly, slowly opened it.' }\end{array}$

21 The tales are in Vidoeski (2000), but the example was written down by Małecki in the 1930 .

22 Example (10) is from Karanfilovski (2009: 70), (11) from Peev (1987: 292), and (12) from Labroska (2003: 109). 
In Kastoria/Kostur region, $n a$ is completely grammaticalized with animate nouns, as in (13) provided in Vidoeski (1998: 89). More examples come from Nestorio/Nestram and other neighboring villages: me vide na mene 'he saw me', a vikna na ženata 'called the woman', gu vidu na Vaneta 'I saw Vane' (Vidoeski, 1999: 91).

$\begin{array}{llllll}\text { Dojdoa } & \text { psite } & \text { tam } & i & \text { go } & \text { zbraa } \\ \text { come-PST.3PL } & \text { dogs } & \text { there } & \text { and } & \text { 3SG.M.ACC.CL } & \text { attack-PST.3PL }\end{array}$

$\begin{array}{lll}\text { na } & \text { toj } & \text { čoveko. } \\ \text { DOM } & \text { DEM } & \text { man-DEF.SG.M }\end{array}$

'The dogs came there and attacked that man.'

It was only much later (the second half of the $20^{\text {th }}$ century) that $n a$-marking was noted further to the north: in the towns of Ohrid, Struga and Debar located in the south-west of the Republic of North Macedonia, but not in ethnic Macedonian villages near Ohrid and Struga. Vidoeski (1998: 125) provides an explanation for this fact claiming that the long and steady migration of inhabitants from mountain villages to the Ohrid region resulted in the interruption of the Ohrid-Struga dialect continuum and subsequent isolation of the urban speech. In addition to this sociolinguistic differentiation, the speech of the Moslem Macedonian-speaking population, who were culturally separated from their Christian neighbors, took its own course of development. In the narrow stretch along the Albanian border, Moslem speakers, known as Torbeš, still keep some archaic features (ibid.: 225), including the optional use of synthetic dative and genitive-accusative forms with masculine kinship terms and proper names (mu reče Stojanu 'tell Stoyan', go vide Stojana 'saw Stoyan'). Another distinctive feature of Torbeš speech in the ethnically mixed Debar region ${ }^{23}$ is the use of na-direct objects ( go videl na Sareta 'saw Sare', ke a dărzat na nevestata 'they will keep the bride').

As mentioned earlier, the use of Dom in Ohrid, Struga and Debar is traditionally accounted for by Aromanian influence. However, Tošev (1970) finds the use of $n a$-objects in Struga surprising because they were not attested in the $19^{\text {th }}$ century Aromanian texts from Struga. He allows for the possibility of Aromanian influence following the migration of Aromanians to Struga (and other towns in Macedonia and Thessaly) after the destruction of Voskopoje/

23 The Debar area, where Albanian-Macedonian bilingualism is common, is populated by ethnic Albanians, Macedonian-speaking Moslems (Torbeš), Macedonians and Turks. The Torbeš polulation lives in almost all villages in Župa (roughly between Ohrid and Struga) and Gora districts (Vidoeski, 1998: 214). 
Moschopolis (Albania) in the end of the $18^{\text {th }}$ century. ${ }^{24}$ Tošev cites 33 examples of $n a$-objects collected from schoolchildren's written assignments in Struga (ibid.: 109). The human $n a$-objects ${ }^{25}$ cooccur with verbs such as 'ask', 'let', 'see', 'look for', 'beg', 'force', 'wait', 'cheat' and several physical activity verbs with a high degree of affectedness: 'kill', 'grab', 'eat', 'beat', 'shoot', etc. In (14) the dislocated $n a$-object is topicalized, as in (15), where the main protagonist is topical due to a sudden change of events (indicated by 'but' and 'then'). In (16) na seems to be discriminating: the second participant, the father, is determined by the generalized possessive dative enclitic $m u$ (masculine instead of the feminine form), which, in the absence of $n a$, creates confusion who met whom.

\begin{tabular}{|c|c|c|c|c|c|c|}
\hline (14) $\quad \mathrm{Na}$ & Đura & ne & go & puštile & $d a$ & odit. \\
\hline DOM & Gjura & NEG & 3SG.M.ACC.CL & let-PRF.3PL & SBJV & go-PRS.3SG \\
\hline
\end{tabular}

$\begin{array}{llllllll}\text { (15) Aleksa } & \text { otišol } & d a & \text { krade } & \text { no togaš } & \text { na } & \text { Aleksa } \\ \text { Aleksa } & \text { go-PRF.3SG } & \text { SBJV } & \text { steal-PRS.3SG } & \text { but then } & \text { DOM Aleksa }\end{array}$
go fatija.
3SG.M.ACC.CL catch-PST.3PL
'Aleksa went to steal something, but then Aleksa was caught.'
(16) Devojčeto go sretna na tatko mu.
girl-DEF.SG.N 3SG.N/M.ACC.CL meet.PST.3SG DOM father 3SG.M.DAT.CL 'The little girl met her father.'

In its advance to the north, DoM also reached the capital Skopje; in the 196os, its use was registered in the speech of many young people (ibid.: 110). Koneski (1986: 203) notes that this innovation spread without any immediate geographic contact with the original sources of change, so its "peculiar presence" in

24 Before its decline (due to several destructions by the Turks in 1769, 1788 and 1816), Moschopolis, a small Aromanian town near Korçë (Albania) was an important economic and cultural center. The strong connection to the Hellenic tradition in education was reflected in the widespread bilingualism of the Aromanian population, as well as in the activities of some prominent local leaders (for instance, Daniel Moschopolites) aimed at the hellenization of the non-Greek Christian communities in the Balkans (Friedman, 20oob; Mackridge, 2009).

25 The only example that he cites with an inanimate entity Zede malku smola i ja izbriša na masata. '(He) took a liitle wax and wiped dom the table' must be a mistake, probably due to the inappropriate choice of the verb 'wipe' (instead of 'spread'), in which case $n a$ is a locative preposition. 
Skopje vernacular should be attributed to the migration of speakers who "imported" it from their dialects and influenced other speakers in adopting this pattern.

The use of na-objects, which has not been mentioned in the dialectal materials, is also attested in a variety of the dialect spoken in Strumica, a small town near the Bulgarian border. Some speakers from this speech community are descendants of refugees from Kilkis/Kukuš (Greece) who were forced to leave their homes in 1913 during Balkan Wars. Most probably, this feature has been transmitted from one generation to another in the last 100 years, so today even young people mark direct objects when comminicating in the local dialect. ${ }^{26}$

To conclude, in Macedonian dialects animacy and the discourse prominence of the patient/theme decide whether the direct object will be casemarked by $n a$. Yet some examples above testify that topicality is also involved in $n a$-marking. Is it then a real case marker? What were the reasons for the rise of DoM in southernmost dialects? In order to answer these questions the results of the diachronic analysis of dialectal sources are presented in the next section.

This section discusses the distribution and the properties of $n a$-objects in the two oldest sources: the Kulakia Gospel and the folk tales in Verkovik's collection. Both manuscripts were created in 1863 in the region north-west of Thessaloniki where Slavic-Greek language contact was most intense. Cyxun (1981: 41) locates the radiation center of the novel marking of direct objects in the "narrow innovation region" near Lagadina region, where the Gospel was created. ${ }^{27}$ As pointed out in the introduction, this change should be accounted for only against the background of a multilingual context and the fact that the village of Kulakia (Chalastra) had a mixed population of Slavic and Greek descent.

26 To obtain more reliable information on ром in this speech community, a judgment acceptability test was conducted on a rather small sample of 40 informants. Of 10 examples the following three with a topicalized $n a$-object got the highest acceptability score: $G a$ pitah na nastavničkata 'I asked dom the teacher', Kola go udri na kučeto! The car dom hit the dog!', and Go udri na kučeto, ne na mačeto 'He hit dom the dog, not dom the cat'.

27 This is an area between the mountain range Vertiskos on the west/northwest and Langada Lake on the east, to the north of Thessaloniki (Greece). 
The analysis is focused on Verkovik's collection because of the narrative style of the folk tales, their secular character and the variety of topics. On the other hand, the Gospel has a unique status among other dialectal materials because it documents a regular use of Dом. This fact suggests a potential "birthplace" of this innovation.

\subsection{The Kulakia Gospel}

In their linguistic analysis of the Gospel text, Mazón and Vaillant (1938: 176-179) discuss the use of $n a$ with direct objects and suggests that it was a recent local innovation. They are cautous in drawing parallels with the Aromanian pattern because of the different general conditions in "Romanian" and in the dialects spoken in the vicinity of Thessaloniki ${ }^{28}$ and argue that the use of $n a$ with direct objects as in mi vide mene 's/he saw me' involves extention of the dative analytic pattern of the type mi rič na mene 's/he said to me'. In their view, the "preposition" na was optionally used with accented syncretic dative-accusative pronouns (mene 'me', tebe 'you'), but the confusion between "unstressed" accusative and dative proclitics (e.g, mi, me 'me') contributed to the spread of $n a$, which came to introduce the "accented" pronominal complement (mi vide na mene 's/he saw dom me').

The distributional analysis of $n a$-objects in the Gospel confirms that this pattern was regularly used in the middle of the $19^{\text {th }}$ century in this dialect: of 277 marked direct objects found in the text only 10 are unmarked. These $n a-$ objects function as complements of 64 verbs; ${ }^{29}$ the most frequent are 'see' (39 tokens), 'listen' and 'ask' (21 tokens), 'send' (20 tokens), 'take' and 'call (14 tokens), 'know' and 'love' (13 tokens), and 'find/meet' (11 tokens).

The referents of the marked objects predominantly encode a specified human participant in the singular, even if the object is coordinated or heads a relative clause (17). The omission of $n a$ is uncommon, mosltly occurring with the noun detito 'the child' as in (18), in which the coordinated object is na-marked.

28 In the original: "les conditions générals n'étant pas les même en roumain et dans les parlers des environs de Salonique" (Mazón and Vaillant, 1938: 176).

29 These are: 'annoint,' 'anger, 'arrest', 'ask,' 'beg,' 'betray', 'baptize', 'buy', 'bless', 'call/summon', 'catch', 'cheat', 'celebrate', 'close', 'comfort', 'crucify', 'cure', 'curse', 'deliver, 'deny', 'destroy', 'divide', 'forgive', 'find,' 'hear', 'hire', 'invite', 'keep', 'know', 'kill', 'leave', 'listen/obey', 'lose', 'look for', 'love', 'meet', 'put', 'raise', 'save', 'see/look', 'send', ‘separate', 'shake', 'stab', 'take', 'take pity', 'teach', 'tempt', 'torment', 'understand,' 'undress', 'wait', 'wipe'. 
(17) Isus $\mathrm{ka}$ a vide na majka mu, Jesus when 3 SG.F.ACC.CL see-PST.3SG DOM mother $3^{\text {SG.M.DAT.CL }}$

$i$ na učenikut... na to šo miluvaši $(69 / 3)^{30}$ and DoM pupil-DEF.SG.M DOM DEM REL love-PST.3SG 'When Jesus saw his mother and the disciple ... the one he loved.'

(18)

$\begin{array}{llllll}\text { I } & \text { on } & \text { stana, } & a & z e l & \text { detito } \\ \text { and he } & \text { rise-PST.3SG } & \text { 3SG.F.ACC.CL } & \text { take-PRF.3SG } & \text { child-DEF.SG.N }\end{array}$

i na majka. $(92 / 4)$

and DOM mother-SG.F

'And he got up and took the child and his mother.'

$\mathrm{Na}$-marking in six instances is found even with unspecified human objects, as in examples (19) and (20), which indicates high degree of regularization of DoM. In (19), the object is a substantivized adjective živ 'the living'.

(19) Šo palati na živ su mrtvite? (148/6) what search-PRS.2PL DOM alive COM dead-DEF.PL 'Why do you look for the living among the dead?'

$\begin{array}{lllllll}\text { (20) } & \text { Ki } & \text { prudosa } & \text { brat } & \text { na } & \text { brat } & i \\ & \text { FUT } & \text { betray-PRS.3SG } & \text { brother } & \text { DOM } & \text { brother } & \text { and }\end{array}$

tatko na detito. (137/9)

father DOM child-DEF.SG.N

'A brother will betray his brother and a father his child.'

The regularization of Dом marking is reflected in the use of na with plural human referents (69 tokens): a vikal Isus na dvanadeset Učeniciti 'Jesus summoned the twelve disciples' (74/1), da miluvat na dušmanite 'to love your enemies' (34/8). Almost a third of these objects (20 tokens) are pronominal (na via i pušti Isus, em m kaža na nih '(dom) them Jesus sent, and he said to them'). The optional use of $n a$ with plural objects may indicate that only topical objects are marked. Example (21) testifies to the fact that topicality is involved in the fur-

30 The numbers in the parenthesis denote the original number of the paragraph in the Gospel and the line where the example is found. 
ther spread of na-marking; in (21) it is emphasized that the two unspecified brothers whom Jesus saw were the $n a$-marked Peter and Andrew. ${ }^{31}$

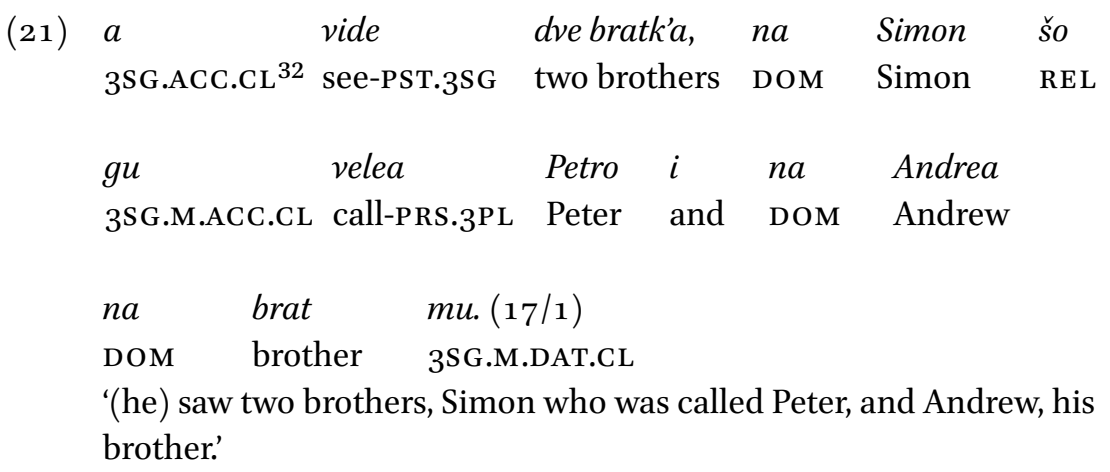

Apart from human referents, $n a$-direct objects may encode animals and inanimate entities (calf, sheep, wolf; body, tomb, land, books). In some cases variation is observed with the same referent: a gleda na vălkot (78/5) vs. a gleda vălkot 'see the wolf' (108/5); or ne mu să našle na snagata mu 'they did not find (dom) his body' (3/16) vs. ne a najdele snagata gospodinova 'they did not find the Lord's body' (148/3). In (22) the object 'tomb' is na-marked but it is not marked in a gledaa grobut 'they were looking at the tomb' (6o/1), which suggests that the optionality in plural and non-human ром marking depends on topicality. The marked object (the tomb) appears after the protagonists of the story "went and" then did something important in the second event.

Proper names are regularly D ом marked. Generally, masculine names in direct object position rarely have the genitive-accusative case ending $-a$, as in fati na Ioana 'arrested John' (143/6), displaying variability with the same verb: a našol na Filip (79/1) vs. našol na Simona (85/9) 'found Philip/Simon'. Moreover, variation with the same nominal is observed: a vide Sfetago duh 'he saw the Holy spirit' (98/7) vs. vlasfimisa na Sfeti Duh 'he cursed (dom) the Holy spirit' (75/5). The absence of $n a$ in Sfetago duh correlates with the preserved genitive form of the adjective typical of the ecclesiastical style.

\footnotetext{
31 Cf. As Jesus was walking beside the Sea of Galilee, he saw two brothers, Simon called Peter and his brother Andrew (Matthew, 4/18).

32 This is a generalized accusative clitic $a$ originally from the accusative 3 sg feminine $j a$.
} 
The most striking property of the Gospel text is the extent of confusion of the preverbal clitics in the case-marking function. Thus, the use of the accusative clitics for $3^{\text {rd }}$ person singular is characterized by a lack of gender and number distinction, so in addition to go/gu 'him', three other pronominal forms occur in free variation: the dative $m u$, the accusative feminine $a$, and the plural accusative $i$. They are found even with the same verb: gu pita na negu $(7 / 16$, $38 / 9)$ vs. mu pita na negu $(33 / 3,46 / 7)$ 'he asked him', or a vidohmi na Afendot 'we saw (dom) the Lord' $(2 / 11 ; 153 / 10)$ vs. i vidoa na Stopanot 'they saw (dom) the Lord (5/5). Variation can also be found within the same sentence, as in (23).

(23) I go fatia aramiite $i \quad m u$ and 3SG.M.ACC.CL catch-PST.3PL robber-DEF.PL and 3SG.M.DAT.CL

sublikoa na negu. (40/9)

undress-PST.3PL DOM he-3SG.M.ACC

'A man was going down from Jerusalem, some robbers caught and stripped him.'

In line with this tendency, the above clitics $i, a, m u$ are also used to casemark $3^{\text {rd }}$ person feminine singular and $3^{\text {rd }}$ person plural direct objects: da i paragorisat na nei 'to comfort (dom) her' (57/25), mu paragorisaa na nea (57/33) 'they comforted (dom) her', a puštia na nea 'they sent (dom) her' (32/5); ka mu vide Isus na nih 'when Jesus saw (dom) them' (21/4), mu lekuva na bolnite ljudi 'he cures (dom) the sick people' (23/1), ki i zagubi na nih 'he will kill (dom) them' (28/12).

Moreover, in several instances two juxtaposed accusative clitics may be found with the same topicalized but not na-marked object (Jesus), as in (24); or reversely, the accusative clitic was often omitted with the $n a$-marked object: na negu da slušiti (139/9) vs. na negu da mu slušiti (138/12) '(dom) him you should listen to'.

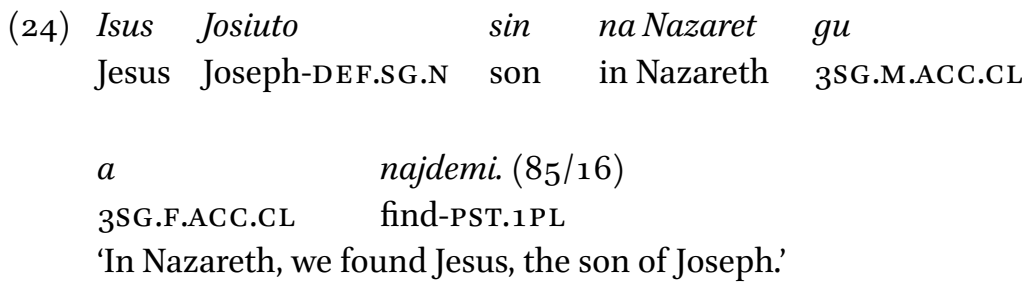

The confused, even erratic clitic use indicates that they substantially lost their case marking function. This is confirmed by examples in which the clitic extended its scope to introduce unspecified nominal complements (cf. ibid.: 179): a vide idno čovek 'he saw a man', on a flegal u idno kaik 'he got into a boat', 
and even to signal dependency of a declarative clause: $\boldsymbol{a}$ znam oti., 'I know that....

It can be concluded that $n a$ in this dialect served as a marker of objecthood: it signalled direct dependency of a nominal complement. Thus na compensated for the undermined role of the clitics, which demostrated much fluctuation of usage.

\subsection{Verkovik Tales}

Even a cursory survey of the two analyzed texts shows that the occurrence of $n a$-objects in Verkovik's tales is not regular. Considering that there are 133 tales, the number of Dом examples in this text is relatively low-only 89-because they are present in less than 30 tales. Such an uneven distribution of $n a$-objects may be attributed to at least two reasons: the tales do not accurately reflect the dialect spoken in this region because even smaller local dialects had their own distinctive features. Hence the collector's interventions into the language cannot be ruled out (Koneski, 1986). Secondly, it is higly possible that Dom at that time was still considered an innovation, not used by all storytellers.

The most frequent verbs that co-occur with $n a$-objects are 'ask' (30 tokens) and 'listen' (20), which together rise to 36 instances ${ }^{33}$ out of 89 . The next more common verbs (with four to five occurrences) are the speech verbs 'beg', 'scold', 'call', and the physical affectedness verbs 'hit' and 'kill/stab', followed by 'see/ look' (three instances), while the rest are represented either with two instances ('force', 'see off', 'find'), or are used only once ('grab', 'meet', 'press', 'let/allow', 'wake up', 'wash', etc. including the psych verbs 'comfort' and 'like'). Examples where $n a$ keeps its locative meaning were excluded, for instance with the verb 'mount' which was used both with or without na 'on': vjahna (na) konja 'mount the horse'. Similarly, several examples with the verb 'hit' in constructions of the type 'give somebody a slap' were not counted.

It should be pointed out that na-marking is still an optional strategy in these narratives. Even the most frequent 'ask' does not take $n a$-objects in all uses, both in unmarked and marked linearizations: Go pitat covekot, toj im veli...'they ask the man, he tells them' (Penušliski, 1985: 228), Ponatamu ke najdeš drug kato mene, nego da go pitaš! 'Futher on, you will find someone like me, him you should ask' (p: 26o). ${ }^{34}$ Such variability is found within the same tale: no DOM is used to mark the object (children) in Ženata gi pita decata 'the woman asked the children' (p: 228), but later in the story when the husband arrives, the object (wife) is marked (25).

33 The collocation pita na sălnceto 'asked (dom) the sun' was used four times in the same tale.

34 The number in the parenthesis (p: \#) indicates the page number in Stefan Verkovik, South Macedonian folk tales (4) (Penušliski, 1985). 


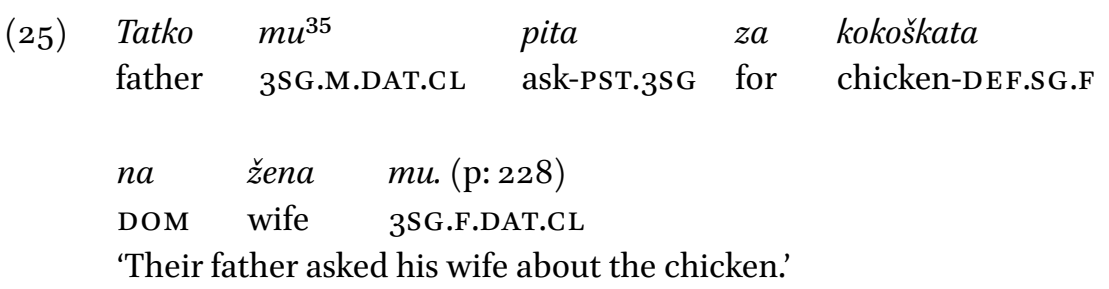

Optionality in marking is observed with the other frequent verb, posluša 'listen/obey': Toj ne posluša na tatko mu 'He didn't listen to (dom) his father' (p: 395), Toj majka ne posluša 'He didn't listen to his mother' (p: 301).

The high number of $n a$-objects with 'ask' and 'listen/obey' (40\%) indicates the affiliation of DOM with particular lexical constructions. Both 'ask' and 'tell' are extremely frequent speech verbs whose recipient arguments are casemarked differently, probably because the second human argument of 'ask' is more patient-like: his/her behavior is manipulated by the agent. ${ }^{36}$ Speakers of these dialects have syntactically leveled the two speech verb constructions by analogy with the dative pattern in 'tell'. What should be taken into consideration is the fact that story tellers predominantly used direct speech: kaža na 's/ he said to', pita na 's/he asked (dom)' without embedding the verbal message in the same sentence. Therefore, it is reasonable to assume that $n a$ spread to other monotransitive verbs from this frequent ditransitive construction. As the frequency distribution shows, the inclusion of other verbs into this patern probably followed the affectedness parameter, conveyed by common verbs of speech, physical activity and even perception and emotion ('beg', 'scold,' call', 'hit', 'kill', 'stab', 'look', etc.). The push may have come from the dative/accusative northern Greek construction discussed in the following section.

The importance of verbal semantics in the spread of this pattern has been noted in several studies on Spanish DOM (von Heusinger and Kaiser, 2007; von Heusinger, 2008). They argue that DOM prefers verbs that take a human direct object: the higher the verb's preference for human objects, the more likely its object is differentially marked. The frequency scale of the verbs discussed above ('ask', 'listen/obey' 'beg', 'scold', 'call', 'allow', 'hit', 'kill', etc.) corresponds to the animacy scale, with the first several verbs selecting only human arguments. Therefore, von Heusinger's conclusion that: "the lexical semantics of the verb is an additional driving force in the diachronic evolution of DoM" (von Heusinger, 2008: 29) seems to be confirmed by the above findings. In section 3 , the

36 Givón (2001: 152) classifies ask within "attempted manipulation" verbs. 
survey of the examples from the urban speech of schoolchildren in Struga (Tošev, 1970) also shows that a similar inventory of verbs was used with human na-objects including verbs such as 'look for', 'wait', 'cheat', 'see', 'praise', etc., and high affectedness verbs 'eat', 'beat', 'shoot', etc.

Another factor contributing to the rise of DOM in these dialects is the optionality of clitic doubling. Given that $n a$-direct objects always encode specific entities known to both conversational participants, they are optionally replicated by accusative proclitics. ${ }^{37}$ In an impoverished case system (typical of these dialects), clitics are instrumental in distinguishing the roles of participants in a transitive situation. Moreover, taking into account the fact that DOM is based on specifity/definiteness, agreement clitics have an important discourse role. Siewierska and Bakker (2008: 293) argue that they serve "as a means of keeping track of referents in the discourse via their index of features. ... [A]greement is thus a form of pronominalization used in preference to free personal pronouns for highly salient discourse referents, which the speaker assumes to be easily accessible to the addressee." Following this line of reasoning, it is possible that when speakers consider the use of a clitic insufficient to indicate salience (and even identification) of the object referent, an additional means is called for-the dative marker $n a$. Its role is to assign a prominent discourse status to the human object referent.

An indicative fact is the optionality of clitic doubling: in almost half of the examples in the analyzed tales the clitic is lacking. This is partly due to the frequent use of the verb posluša 'listen/obey' and moli 'beg', regularly without an accusative clitic, while with pita 'ask' the clitic is used inconsistently. Since an accusative clitic has a discriminatory role, its absence may have been an additional reason for the use of $n a$. In some cases disambiguation between the agent and the patient is performed by the genitive-accusative case ending - $a$, still kept in nouns denoting male individuals. In this text, it is found in combination with $n a$, illustrated in (26) and (27).

$\begin{array}{lllll}\text { Izvadi } & \text { sabjata } & i & \text { go } & \text { zakole } \\ \text { take-PST.3SG } & \text { sword-DEF.F } & \text { and } & \text { 3SG.M.ACC.CL } & \text { stab-PRF.3SG.M }\end{array}$

na kalugjera (p: 136)

DOM monk-sG.M.ACC

'He took out the sword and stabbed the monk.'

37 According to von Heusinger and Kaiser (2003), the use of Spanish ром depends on specificity and animacy, while clitic doubling is determined by definiteness. Clitic doubling very often co-occurs with the particle $a$ (ibid: $5^{6-57}$ ). 


\begin{tabular}{|c|c|c|c|c|}
\hline $\begin{array}{l}\text { Koga } \\
\text { when }\end{array}$ & $\begin{array}{l}\text { videla } \\
\text { see-PRF.3SG.F }\end{array}$ & $\begin{array}{l}\text { mnogu } \\
\text { many }\end{array}$ & $\begin{array}{l}\text { grobišta, } \\
\text { graves }\end{array}$ & $\begin{array}{l}\text { pitala } \\
\text { ask-PRF.3SG.F }\end{array}$ \\
\hline carskij & čoveka & što & ja & vodeše... (p: 465) \\
\hline royal & man-SG.M.ACC & REL & 3SG.F.ACC.CL & lead-Pst.3sG \\
\hline
\end{tabular}

It seems that there is no regular correlation between the use of $-a$ and $n a$ in these folk tales: we find Dom with case-marked objects: go pita na siromaha 'he asked the poor man' (p: 73), pitaj na brata ti 'ask (dom) your brother' (p: 74), go zakoli na kalugjera 'he stabbed (dom) the monk' (p: 136), or no DoM even with case-marked focused participants (Što ne zakoluvaš Arapina? Why don't you stab the Arab? (p: 416).

On the semantic plane, the frequency distibution of $n a$-objects corresponds to the animacy scale: of 89 referents (some used twice), the majority encodes human beings, and only several objects refer to personified animals (the snake/ bear/frog/ox/horse/chicken), and even fewer objects to inanimates (the sun/ finger/pleadings). Plural objects referring to individuals and animals are found only in eight instances: pita na decata 'ask (dom) the children' (p: 230), posluša na svatovite 'listened (dom) to his in-laws' (p: 349), udriva na volovite 'hit (dom) the oxen' (p: 225), but also with an abstract noun (pleas, tears), as in $(28)$.

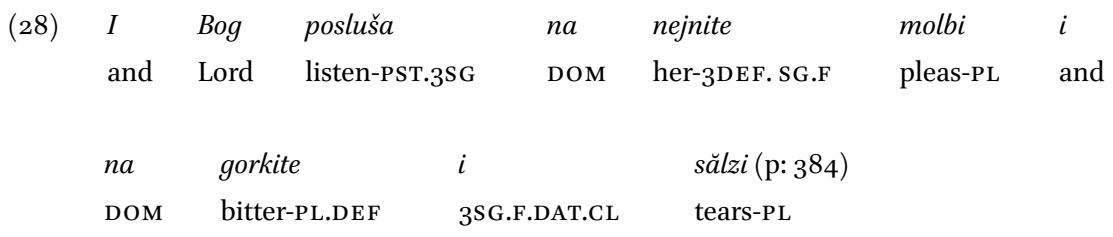

'And the Lord listened to her pleas and to her bitter tears.'

In the discussion in section 3, the presence of Dom in examples (10-16) was explained in terms of discourse prominence and topicality. Although topicality is difficult to pinpoint in a written text, some syntactic and contextual clues are helpful. In example (29), no ambiguity arises between the subject and the object because they differ in person (we vs. the ox), yet the direct object is marked by na. Previously in the story, the protagonists came across an old ox. This personified animal becomes important for the plot: the protagonists want to ask advice from it and therefore it is highly topical. 


\begin{tabular}{|c|c|c|c|c|c|c|}
\hline Ajde & $d a$ & se & pitame & na & tova & vol! (p: 244) \\
\hline $\mathrm{HORT}^{38}$ & SBJV & REFL & ask-PRS.1PL & DOM & DEM & ox \\
\hline
\end{tabular}

A similar topicality explanation can account for the use of $n a$-marking on the abstract object 'soul' in (30): the temporal clause with l'u 'at the moment' creates suspense. The listener's expectation is resolved in the main clause, where the definite object carries the information focus. However, $n a$ here may be interpreted as a locative preposition, and not as a topicality marker.

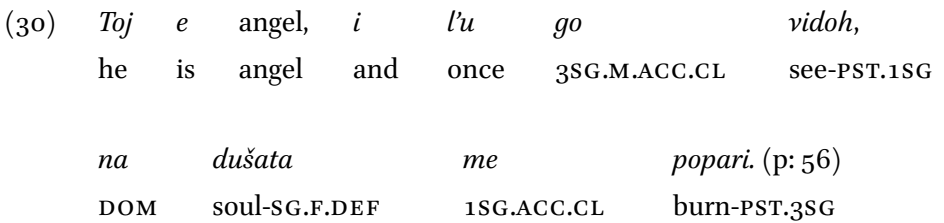

'He is an angel, the moment I saw him, he burned my soul/ he burned me on my soul.'

Proper names marked with $n a$ are not so common because the participants are referred to with kinship or occupational terms. Object personal pronouns, used in 12 instances, often bear an informative (31) or a contrastive stress (32), signalling high topical status. Dом is not used here for disambiguation because the object pronouns are case-marked.

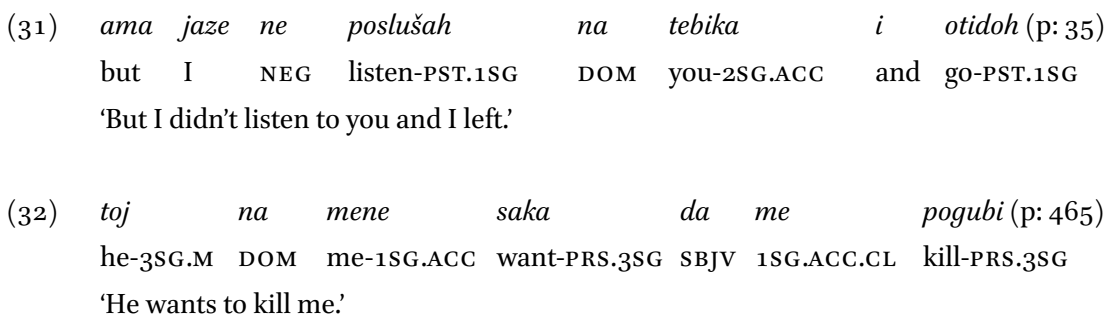

A tendency to mark topical participants with DOM is observed in contexts where there is a sudden change of situation, crucial to the resolution of a plot. This is signaled by the adverb l'u 'at the very moment', the inceptive fati 'start' (33), or the adverb 'immediately' (34).

$38 \quad$ Ajde is a common Balkan hortative particle. 
(33) L'u fati da ja pita za žabata as start-PST.3SG SBJV 3SG.F.ACC.CL ask-PST.3SG DOM frog-DEF.SG.F

dali ima $i$ drugi žabi sos nea. (p: 57) if have-PRS.3sG and other frogs-PL COM her-SG.F.ACC 'And then he started to ask the frog if there were other frogs with it.'

(34) Zaednaš sos sabjata go čini immediately COM sword-SG.M.DEF 3 SG.M.ACC.CL make-PST.3SG

na protudrako parčinka-parčinka ${ }^{39}$ (p: 137)

DOM archdevil-sG.M.DEF piece-piece

'Immediately he cuts the archdevil into pieces.'

The fact that na-objects occur in the main clause supports the hypothesis about their high topicality. The previously introduced protagonist (the bear) is in the rheme part of the sentence (35). What is important for the story line is that the main protagonists finally found the bear, which participates in the narrative by providing the desired change in the course of events.

(35) Kato go najdoha oklavan Arapinot, when 3 SG.M.AcC find-PST.3PL killed-PtcP Arab-DEF.M

otidoha $i$ na mečkata ja najdoha. (p:380) go-PST.3PL and DOM bear-DEF.SG.F 3SG.F.ACC.CL find-PST.3PL 'When they found the dead Arab, they left and found the bear.'

The above examples demonstrate the two main functions of the na-marker, prominence and topicality, which seem to be ordered implicationally: the former may imply the latter but not vice versa.

Table 1 presents the numerical findings in the two texts. The comparison of the examples from the Gospel and Verkovik's tales leads to the conclusion that DOM marking is more regular in the former: only 3.5\% of all direct objects in the Gospel were unmarked compared to $37 \%$ in Verkovik's tales. Another difference in Dом distribution involves plural object marking: the Gospel text has almost three times more na-marked plural objects $(25 \%)$ than the Verkovik text $(10 \%)$.

39 A calque from the Greek kommatakia-kommatakia. Such adverbial reduplication is common in spoken Greek. 
TABLE 1 The distribution of $n a$-marked objects (DO) in the two oldest texts

\begin{tabular}{|c|c|c|}
\hline & Kulakia Gospel & Verkovik's tales \\
\hline Marked DO (with $n a)$ & $277(96.5 \%)$ & $89(73 \%)$ \\
\hline Unmarked DO (without na) & $10(3.5 \%)$ & $33(27 \%)$ \\
\hline Total DO & 287 & 122 \\
\hline Marked animal referents & 3 & 7 \\
\hline Marked inanimate referents & 4 & 4 \\
\hline Marked plural referents & $69(25 \%)$ & $9(10 \%)$ \\
\hline Verbs with marked DO & 64 verbs & 25 verbs \\
\hline
\end{tabular}

To conclude, the use of Dом marking seems to have been governed by different functions in the two examined texts. The language of both analyzed texts testifies of a strong Greek influence both in structure and lexicon. ${ }^{40}$ The very regular use of ром in the Gospel indicates that in that dialect na was grammaticalized into a case marker. However, the irregularity of Doм marking in Verkovik's tales should rather be attributed to the interplay of animacy and discourse prominence criteria. Is it, then, a case marker or a pragmatic marker? In order to answer this question we should first discuss the possible reasons for its emergence.

As was outlined in the introduction, DOM in Macedonian southernmost dialects has been traditionally ascribed to contact, though certain doubts in the validity of the contact hypothesis were presented in the previous discussion.

40 Apart from morphosyntactic Balkan features, both texts contain numerous Greek and Turkish lexical loans that involve both "cultural" vocabulary and highly colloquial, discourse-based vocabulary used in "everyday interactions among speakers that are essentially conversational in nature" (Friedman and Joseph, 2014: 15). The authors refer to the latter type as Essentially Rooted In Conversation (ERIC) loans. Examples of such Greek loans in Verkoviḱs tales include common lexemes (e.g. ftesa 'be guilty', argisa 'be late', zulepsa 'envy', panukla 'plaque', etc), idiomatized syntactic constructions (e.g. vide-paravide 'After seeing and realizing that') and discourse particles (e.g. $b a$ - emphatic negation). 
Topolinjska (1995: 95) considers the construction in these dialects a syntactic innovation resulting from the contact with Greek: "... it spreads in the dialects which undergo major interference on the part of non-Slavic Balkan languages, above all Greek; i.e. in the dialects in which the inherited Slavic morphosyntactic system is in the process of retreat." She provides an overview of the distribution of $n a$-objects in southern Macedonian dialects noting that their occurrence to a great extent coincides with the dialects ${ }^{41}$ where other innovations occurred, for instance the generalization of the $3^{\text {rd }}$ person singular accusative clitic to a single case marker of direct dependency (ibid.: 97).

The exposure of southernmost dialects to strong Greek influence primarily created favorable conditions for the emergence of DOM, which as pointed out above, appeared in the narrow innovation region near Lagadina Lake, north of Thessaloniki (Cyxun, 1981: 41). ${ }^{42}$

The intensity of contact with Greek there may be illustrated by example (36) from našta (lit. 'our') dialect spoken in the village of Liti (former Ajvati) in Greece (Adamou, 2009: 15). The two contact-induced features in this example show changes in the grammar of nominal and verbal systems: proper names are marked with definite articles and the subjunctive marker $d a$ is replaced by the Greek equivalent $n a$ in the dependent clause. In addition, clitic doubling is absent (as in the Greek translation equivalent).

\begin{tabular}{|c|c|c|c|c|c|}
\hline 36) $\begin{array}{l}d a \\
\text { sB JV }\end{array}$ & $\begin{array}{l}\text { vikniš } \\
\text { call-PST.2SG }\end{array}$ & $\begin{array}{l}n a \\
\text { DOM }\end{array}$ & $\begin{array}{l}\text { Mariata } \\
\text { maria-DEF.F }\end{array}$ & $\begin{array}{l}n a \\
\text { SBJV }\end{array}$ & $\begin{array}{l}d o j . \\
\text { come-PRS.3SG }\end{array}$ \\
\hline
\end{tabular}

To account for the use of ром in the analyzed texts we refer to the corresponding Greek object constructions. The hypothesis is that the syncretism of dative and accusative case markers in the northern Greek dialects ${ }^{43}$ in Modern Greek led to the loss of distinction between direct and indirect object constructions in southernmost Macedonian dialects.

In Modern Greek, dependency between the verb and its definite object is indicated by a casemarked preposed definite article marked for agreement

41 In southern Macedonian dialects the accusative relation is encoded by the construction consisting of the clitic $j a+(n a)+$ noun (casus generalis), where $j a$ was generalized from 3 sg.f, while $n a$ is optional. In some other dialects, the generalized clitic is the masculine go (Topolinjska, 1995: 97).

42 This is an area between the mountain range Vertiskos on the west/northwest and Langada lake on the east, near Thessaloniki (Greece).

43 Accusative object pronouns for indirect objects are used north and east of the line which runs down the ridge of Mount Pindos, south of Thessaly, south of Sporades and of Lesbos (Browning, 1969: 123). 
with the object noun (Vlepo tin Maria 'I see Maria', Vlepo ton Petro 'I see Peter'). Dative case was lost in Modern Greek, its functions divided between the genitive and the accusative. ${ }^{44}$ In northern Greek dialects the indirect object pronouns are in the accusative, wheras in the southern dialects they are in the genitive (Horrocks, 2010: 116). Northern dialects formally distinguish between adverbal and adnominal uses of pronominal casemarked clitics denoting dependency, i.e. between the clitic marking verbal dependency of the indirect object (accusative) and the possessive clitic marking nominal dependency (dative), as in: Ipa ton patera tu 'lit. I said to father his', but the southern dialects use the genitive clitic for both dependencies (Ipa tu patera tu).

It follows that in northern Greek dialects, both direct and indirect dependency are expressed with a syncretic accusative definite article, for instance ton for masculine sungular as in (ton) ipa ton Petro 'I told Peter', whereas object doubling by a preverbal clitic is not obligatory: (ton) idha ton Petro 'I saw Peter'. The same case marker (e.g. ton, 3sg masculine) in the pre-object position makes the two syntactic patterns ( 37 and 38 ) identical.

$\begin{array}{llllll}(37) & \text { (Ton) } & \text { ipa } & \text { ton } & \text { Petro. } & \text { 'I told Peter.' } \\ (38) & \text { (Ton) } & \text { idha } & \text { ton } & \text { Petro. } & \text { 'I saw Peter.' } \\ (39) & \mathrm{Mu} & \text { kažav } & \text { na } & \text { Petre. } & \text { 'I told Peter.' } \\ (40) & \text { Go } & \text { vidov } & / & \text { Petre. } & \text { 'I saw Peter.' }\end{array}$

In the analytic dative pattern in Macedonian (and Bulgarian), the preposition $n a$ occupies the same syntagmatic slot as the Greek casemarked article: $M u$ kažav na Petre 'I told Peter' (39). This results in syntagmatic symmetry between the Greek dative/accusative construction and the South Slavic dative construction, whereas the accusative pattern (40) disrupts this structural symmetry

44 The Greek dative-accusative syncretism is related to the gradual loss of dative at the expense of the accusative. The spread of the accusative to the dative domain was first attested in locative contructions (eis+accusative instead of en+dative) already in the New Testament and the papyri in the $3^{\text {rd }}$ century (Horrocks, 2010: 154). The loss of dative was triggered by its unstable position in Byzantine Greek (at least as early as the $9^{\text {th }}$ century). The neutralization of vowel length in some nominal paradigms resulted in dativeaccusative homophony. Apart from the perils of sound change, the polyfunctional dative case was semantically obscure as it coded both possessive and several adverbial functions. According to Horrocks (ibid: 284), in spoken Koine the functions of the dative were "steadily transferred either to the accusative or genitive noun phrases, which required prepositional support to code indirect objects". In Modern Greek, the accusative prepositional pattern is preferred in spoken language, e.g. the 3sg masculine marker ston (preposition $s+$ accusative article ton) + acc NP as in Ipa ston Petro compared to the genitive-based indirect object pattern in the standard: tu+gen NP, as in Ipa tu Petru 'I told Peter'. 
due to an empty syntagmatic slot filled with the accusative/dative article ton in both Greek patterns. If the preposition $n a$ in these dialects was perceived as a functional equivalent of the Greek casemarked article, it is highly possible that $n a$ was inserted in the accusative construction by analogy. In fact, $n a$ replicates the Greek preposed article that signals dependency. This entails that the iconicity principle facilitated the use of $n a$ in the accusative construction (40) whereby causing structural equivalence of the new accusative pattern not only with its dative counterpart (39), but also with both case constructions (37 and 38 ) in contact with Greek dialects. The generalization of the dative pattern modeled after the Greek oblique pattern should be qualified as replication (Heine and Kuteva, 2005, 2006), ${ }^{45}$ or construction-oriented pattern-replication (Matras and Sakel, 2007:843; Matras, 2009:146), rather than syntactic borrowing (Harris and Campbell, 1995) ${ }^{46}$ because only the pattern was copied and $n a$ was subsequently decategorized via grammaticalization.

Although Adamou (2009) maintains that Aromanian presence is not documented in the wider area of Liti (former Aivati), ${ }^{47}$ certain Aromanian influence in the "narrow innovation region" north of Thessaloniki cannot be totally dismissed. For instance, Aromanians (Vlachs) visiting Ajvati village where "našta variety" was spoken (ibid.) are mentioned in local folk songs. ${ }^{48}$ Yet, there is no direct evidence regarding the use of Dom markers in Aromanian spoken in this area in comparison to the attested $p i$ in the Ohrid dialect (Markovik, 2007) or pri/pra in Krania in Thessaly, Greece (Sobolev, 2008).

The decisive role of bilinguals in generating contact-induced changes is related to their need to reduce the cognitive load of two language systems. As Matras observes (2009:151): "There is pressure on bilingual speakers to simplify the selection procedure by reducing the degree of separation between the subsets of the repertoire, allowing the two 'anguages' to converge." It is possible then, that bi/multilingual speakers of those Slavic dialects whose analytic case systems were under restructuring chose to replicate a more transparent

45 Defined by Heine and Kuteva (2006: 49) as: "a process whereby a language, called the replica language $(\mathrm{R})$, creates a new grammatical structure $(\mathrm{Rx})$ on the model of some structure $(\mathrm{Mx})$ of another language, called the model language $(\mathrm{M})$ ".

46 Harris and Campbell (1995: 122) use this term for a change in which a foreign syntactic pattern is duplicated and "incorporated into the borrowing language through the influence of a donor pattern found in a contact language".

47 According to the document from 1906 (http://www.lithoksou.net/p/oikismoi-tis-thessa lonikis-poy-arxizoyn-apo), Aivati, a Christian village to the north-east of Thessaloniki (Greece) had 200 homes and two Greek schools (for boys and for girls). Its population spoke a "Slavic idiom" but the majority had learned Greek.

48 In a wedding song from the beginning of the $20^{\text {th }}$ century the author complains that Vlachs have arrived in the village and s/he does not understand their language (Adamou, 2009: 15). 
non-Slavic case pattern. Once a borrowed or replicated pattern "takes hold in a language", its spread is regulated by language-internal mechanisms (cf. Joseph, 2000). Such syntactic patterns contribute to word-for-word translatability of utterances in everyday code-switching practice of bilingual speakers. It is not accidental the "innovation region" of this pattern was in the vicinity of Thessaloniki, ${ }^{49}$ an important sea-port and a densely populated multi-lingual urban area during the Byzantine and Ottoman period.

The effects of Greek contact in this region are reflected not only in the destabilization of the pronominal case system, but also in direct borrowing. Matras and Sakel (2007: 834) point out that in language contact situation bilinguals: "avail themselves of the expressive means of both languages, but can only do so if they are able to identify parallel items in the two languages as translation equivalents."

However, sociolinguistic factors alone are not sufficient to explain a linguistic change, such as the rise of Dом in southern Macedonian dialects. Matras (2007: 68) argues that internal factors are more important because they "license" speakers to "dismantle the mental demarcation boundaries that separate their individual languages". Therefore, it is assumed here that a combination of radical language changes in the nominal system has created the right ground for the emergence of DOM in southern Macedonian dialects: the existing pattern of dative $n a$-constructions, generalization of the preposition $n a$ for marking dependency relations, generalization or confusion of clitics, the loss of the accusative ending $-a$ in masculine (human) nouns.

Exposed to a strong Greek influence in the south, the predominantly analytical case system in these dialects underwent further restructuring. The only remaining case ending was the accusative $-a$ in nouns referring to specific male individuals (brata mu 'his brother', popova sina 'the priest's son', etc.). The accusative case even encroached onto the nominative case in a personal pronoun paradigm, as in $(41)^{50}$ where the accusative vas is used instead of the nominative vie 'you'.

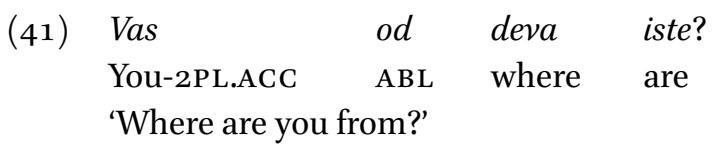

49 Joseph (2000: 142) characterizes northern Greece in general, and Thessaloniki in particular, as areas "where since the Medieval period (1000-1600) speakers of Greek, Slavic (i.e. emerging Macedo-Bulgarian), and Albanian would have come in sustained and close contact with one another on a daily basis, providing opportunities for the effects of language shift, imperfect learning, interspeaker accommodation, etc.".

5o The example is from Cyxun (1981: 47). See example (9) ne te sakam na ti 'I don't love you' for the opposite use. 
As discussed in the previous section, the formal boundary between accusative and dative clitics was blurred, which is illustrated in the example from Vatilak (Topolinjska, 1995: 97): on mu hvărli klučovite i go veli 'he threw the keys to him and said to him'. Here the accusative go 'him' is used instead of the dative $m u$ 'to him', probably following the Northern Greek pattern, where both $m u$ and $g o$ are rendered by the accusative/dative ton. The same type of replacement, but now in feminine clitics is often found in Verkovik's folk tales: Carot ja veli na devojkata 'The king says to the girl' (p: 284), se moli na zmijata i ja veli 'he begs the snake and says to her' (p: 244) where the accusative ja 'her' replaced the dative $i$ 'to her'.

Even more radical changes in the nominal system are documented in the language of the Gospel. The data presented in the previous section demonstrate the loss of gender and number distinctions both in the nouns and preverbal clitics. The case relations became opaque because $3^{\text {rd }}$ person clitics were used to code both direct and indirect dependencies; in addition, gender and number differences were neutralized. These changes seriously affected agreement and case relations.

Moreover, the language in the analyzed texts testifies to the destabilization of other nominal categories. The tendency for generalization and simplification is pronounced ${ }^{51}$ in the category of number: the use of a single plural form instead of two forms with monosyllabic masculine nouns (e.g. sina instead of sinovi), and the regularization of irregular plural marking (čovek 'man' - čoveci, instead of luǵe 'men, people'). Gender was even more affected: plural gender distinctions were neutralized, the differences between some masculine and neuter nouns were erased (Koneski, 1986: 173), some nouns "changed" gender, which is evident in the modifier agreement, e.g. $\operatorname{moj}(\mathrm{m}) \operatorname{pismo}(\mathrm{n})$ 'my letter', tretiot $(\mathrm{m})$ večer $(\mathrm{f})$ 'the third evening', etc.

Another factor enabling the intrusion of the marker na may have to do with the high frequency of the preposition $n a$. Under the influence of the Greek preposition is $(s)$ the preposition $n a$ considerably widened its semantic scope in these dialects. Besides the original meaning of surface support ( $\mathrm{na}$ ' on'), ${ }^{52}$ it encodes relations of containment ( $v o$ 'in'), direction ( $v o$ 'to') and proximity ( $k a j$ 'at').

$5^{1}$ This tendency is also very strong in the verbal system, for instance, the imperfective aspect in some verbs has been regularized with the addition of the imperfectivizing suffix -uva:zemuva 'take', trebuva 'need', skoknuva 'jump', čuknuva 'knock', instead of zema, treba, skoka, čuka.

$5^{2}$ The goal meaning was retained in $n a$, which motivated its extention to the purpose domain. 
It is necessary to look at all these language changes as part of a wider process, and not as isolated instances. The narrow innovation region of $n a$-objects was part of a wider contact territory ${ }^{53}$ within which the analytical dative $n a$ construction appeared (Cyxun, 1981: 41). This secondary innovation was "engrafted" over the primary innovation of the analytic dative contructions: $n a+$ casus generalis of a noun or a pronoun (producing analytic paradigms $n a$ mene/tebe/nego, etc.). Nominal case endings were lost, though some dialects kept the accusative $-a$ in singular human nouns. The introduction of $n a$ probably started as a compensating mechanism for the loss of the differentiating function of clitics aiming to restore the distinguishability between the human male object and the human male subject, but later spread to other participants. In its new role of a case marker, $n a$ made redundant the genitiveaccusative masculine inflection $-a$.

Some authors suggest that the ending $-a$ represents a DOM strategy in Balkan Slavic languages (Adamou, 2009) given that $-a$ marks animacy and might appear to be in complementary distribution with $n a$. This hypothesis is appealing but needs more historical backing, because the evidence from the Kulakia Gospel shows seldom and optional use of $-a$, in spite of the regular presence of the $n a$-pattern. It is true that $n a$-objects are not attested in the dialects where the case marker - $a$ was preserved: in the Konikovo Gospel (end of $18^{\text {th }}$ century) masculine nouns bear -a: ami da vidat $i$ Lazara 'but for them to see Lazarus' (Lindstedt et al., 2008: 175) and in the Pomak dialect ${ }^{54}$ feminine names ending in consonant get the ending -a: Husein ištja Meriema 'Husein liked Meriem'; however, synthetic case has not been fully lost there (Adamou, 2009: 388) as in davam čokolada detinjem 'I give chocolate to the children'.

It can be concluded that Dом in the the innovation zone of Kulakia region and DоM in the dialects to the north of that region were motivated by different reasons: the need for distinguishability between two (human) participans in the former, and the need for topicality in the latter. This hypothesis is supported by the following conclusions drawn from the analysis of the Verkovik folk tales: (a) na-marking of objects was an optional strategy mostly limited to verbs that are semantically tied to animacy, (b) its use was motivated by the need to indicate objecthood of human participants, inherently associated with discourse prominence, (c) na-marking subsequently spread onto topical participants suspending the animacy parameter.

53 The area between Prespa Lake and the mountain ridge Grammos extending to the south along the rivers Vardar/Axios and its tributary Crna.

54 A Slavic dialect spoken by a predominantly Moslem minority in eastern Thrace, Greece (Adamou, 2010). 
Therefore, it is possible to assume an evolutional scenario for DOM in southernmost Macedonian dialects: $n a$ was triggered by the animacy-based differentiating function of case-marking, coocurring with verbs that have human referents (agent/theme). The spread of the pattern to physical affectedness verbs increases the prominence-based indexing function (agent/patient). In other words, what started as a differentiating strategy intended to distinguish the roles of human participants (i.e., a case marker in Kulakia dialect), resulted in "promoting" the indexing function inducing prominence or topic worthiness. ${ }^{55}$ Speakers in narratives, tend to treat prominent objects as topical (they are discourse-old but important participants), thus associating prominence with topicality. Such a scenario explains the regularity of Dом in the innovation zone of Lagadina (north of Thessaloniki) and a broader referential scope of Dом in other southernmost dialects.

It can be concluded that language-internal processes played an important role in the rise of this innovative pattern. However, the role of contact was to create a multilingual favorable context. Does then the rise of DOM belong to internally or externally motivated changes? It seems that this change defies straightforward classification in either category because the difference between them is a "matter of degree and not a matter of kind" (Joseph, 2000: 158).

This paper aims to prove that DoM in peripheral Macedonian dialects was caused in contact situations by the interaction of iconicity and economy principles. The iconicity principle involves speakers' need to overtly mark the pragmatic and the semantic aspects of direct dependency of human patients, i.e. to mark prominence differently from agreement. The economy principle is reflected in reducing two oblique case patterns into one to encode objecthood. Contact indirectly triggered the emergence of ром because of its active role in the demise of the inherited inflected case system and because contact nonSlavic languages used (and still use) a direct dependency pattern with an element preceding the object nominal. In a multilingual environment of the Balkan Sprachbund, speakers' attempt to communicate more effectively resulted

55 De Swart (2007: 133) argues that "there is some evidence for the claim that the prominence-based strategy developed from the recoverability strategy in the history of Spanish". 
in a greater need for clarity of communication (cf. Friedman, 2000a: 1348). The domineering communicative principle in Macedonian dialects was the identification of referents through "strengthening of the markers of referential categories" (Topolińska, 1995: 245). Therefore, the appearance of Dом on specific nominals is not surprising: for a successful communication it was important for the listener to link the individuated and prominent (human) referent in the discourse to its external anchor. Contact with Greek (and Aromanian) offered an appropriate model at a time when case marking suffered losses in categorial distinctions. In contact situations, changes involving extensive grammatical simplification increase the necessity to disambiguate the roles of sentence participants and mark the second human participant as prominent and/or topical.

The marker $n a$ can be viewed as a discourse device whose emergence reflects the main characteristics of the Balkan Sprachbund-isomorphic structural patterning and translatability. On this view, contact acted as a favorable context within which the grammaticalization of $n a$ occurred. Therefore, the rise of DOM in southermost Macedonian dialect exemplifies a contact-related rather than a contact-induced change.

\section{References}

Adamou, Evangelia. 2006. Le nashta. Description d'un parler slave de Grèce en voie de disparition. München: Lincom.

Adamou, Evangelia. 2009. Le marquage différentiel de l'objet en nashta et en pomaque (Slave, Grèce). Bulletin de la société linguistique de Paris 104 (1): 383-409. Dor: 10.2143/BSL.104.1.2046996.

Adamou, Evangelia. 2010. Bilingual speech and language ecology in Greek Thrace: Romani and Pomak in contact with Turkish. Language in Society 39: 147-171. DoI: 10.1017/So047404510000035.

Aissen, Judith. 2003. Differential Object Marking: Iconicity vs. Economy. Natural Language \& Linguistic Theory 21: 435-483. DOI: 10.1023/A:1024109008573.

Asenova, Petya and Vassilka Aleksova. 2008. Laspect balkanique de la nota accusativi personalis. Zeitschrift für Balkanologie 44 (1):1-22.

Bossong, Georg. 1984. Animacy and Markedness in Universal Grammar. Glossologia 39 $(2-3): 7^{-20}$.

Browning, Robert. 1969. Medieval and Modern Greek. Cambridge: Cambridge University Press.

Bužarovska, Eleni. 2001. Accusative and Dative Clitics in Southern Macedonian and Northern Greek Dialects. Balkanistica 14: 1-17. 
Bužarovska, Eleni. 2017. Differencirovannoe markirovanie ob'ekta v yugo-zapadnyx makedonskix diyalektax Ohrida i Strugi. Rhema 3: 65-87.

Chiriacescu, Sofiana and Klaus von Heusinger. 2010. Discourse Prominence and Pemarking in Romanian. International Review of Pragmatics 2 (2), 298-332. DoI: 10.1163/187731010X528377.

Civjan, Tatjana V. 1979. Sintaksicheskaya struktura balkanskogo yazykogo soyuza. Moskva: Nauka.

Comrie, Bernard. 1989. Language Universals and Linguistic Typology, 2nd ed. Chicago: University of Chicago Press.

Cyxun, Gennadij. 1981. Tipologicheskie problemy balkanoslavyanskogo yazykovogo areala. Minsk: Nauka i texnika.

Dalrymple, Mary and Irina Nikolaeva. 2011. Objects and Information Structure. Cambridge: Cambridge University Press.

Escandell-Vidal, Victoria. 2009. Differential object marking and topicality: The case of Balearic Catalan. Studies in language 33 (4): 832-884. DOI: 10.1075/sl.33.4.02esc.

Friedman, Victor A. 2000a. Pragmatics and Contact in Macedonia: Convergence and Differentiation in the Balkan Sprachbund. Južnoslovenski filolog 56 (3-4): 1343-1351.

Friedman, Victor A. 200ob. After 170 Years of Balkan Linguistics: Whither the Millennium? Mediterranean Language Review 12: 1-15. Downloadable at http://mahimahi .uchicago.edu/media/faculty/vfriedm/153Friedmanoo.pdf (accessed June 23, 2016).

Friedman, Victor A. and Brian D. Joseph. 2014. Lessons from Judezmo about the Balkan Sprachbund and contact linguistics. International Journal of the Sociology of Language 226: 3-23. DOI: 10.1515/ijsl-2013-0073.

Givón, Talmy. 2001. Syntax: An Introduction (1), rev. ed. Amsterdam/Philadelphia: John Benjamins.

Gumperz, John J. and Robert Wilson. 1971. Convergence and creolization: a case from the Indo-Aryan/Dravidian border in India. In Dell H. Hymes (ed.), Pigdinization and creolization of languages, 151-167. Cambridge: Cambridge University Press.

Gundel, Jeanette K., Nancy Hedberg, and Ron Zacharski. 1993. Cognitive Status and the Form of Referring Expressions in Discourse. Language 69 (2): 274-307. DoI: $10.2307 / 416535$.

Harris, Alice C. and Lyle Campbell. 1995. Historical Syntax in Cross-Linguistic Perspective. Cambridge: Cambridge University Press.

Haspelmath, Martin. 2007. Ditransitive alignment splits and inverse alignment. Functions of Language 14 (1): 79-102. DoI: 10.1075/fol.14.1.o6has.

Heine, Bernd and Tania Kuteva. 2005. Language Contact and Grammatical Change. Cambridge: Cambridge University Press.

Heine, Bernd and Tania Kuteva. 2006. The Changing Languages of Europe. Oxford: Oxford University Press. 
von Heusinger, Klaus. 2008. Verbal Semantics and the Diachronic Development of

Differential Object Marking in Spanish. Probus 20 (1): 1-31. DOI: 10.1515/PROBUS .2008.001.

von Heusinger, Klaus and Georg A. Kaiser. 2003. The Interaction of Animacy, Definiteness and Specificity in Spanish. In Klaus von Heusinger and Georg A. Kaiser (eds.), Proceedings of the Workshop "Semantic and Syntactic Aspects of Specificity in Romance Languages", 41-65. Konstanz: Universität Konstanz.

von Heusinger, Klaus and Georg A. Kaiser. 2007. Differential Object Marking and the lexical semantics of verbs in Spanish. In Georg A. Kaiser and Manuel Leonetti (eds.), Proceedings of the Workshop "Definiteness, Specificity and Animacy in Ibero-Romance Languages”, 85-110. Konstanz: Universität Konstanz.

von Heusinger, Klaus and Georg A. Kaiser. 2011. Affectedness and Differential Object Marking in Spanish. Morphology 21 (3-4): 593-617. DOI: 10.1007/s11525-010-9177-y.

Hill, Virginia. 2013. The Direct Object Marker in Romanian: A Historical Perspective. Australian Journal of Linguistics 33 (2): 140-151. DOI: 10.1080/07268602.2013.814527.

Hopper, Paul. J. and Sandra A. Thompson. 1980. Transitivity in grammar and discourse. Language 56 (2): 251-299. DOI: 10.2307/413757.

Horrocks, Geoffrey C. 2010. Greek: a history of the language and its speakers. Chichester/ Malden, Mass.: Wiley-Blackwell. DoI: 10.1002/9781444318913.

Ilievski, Petar H. 1988. Balkanološki lingvistički studii. Skopje: IMJ.

Joseph, Brian D. 200o. Processes of Spread for Syntactic Constructions in the Balkans.

In Christos Tzitzilis and Christos Symeonidis (eds.), Balkan Linguistik: Synchronie und Diachronie, 139-150. Thessaloniki: University of Thessaloniki.

Joseph, Brian D. 2010. Language contact in the Balkans. In Raymond Hickey (ed.), The Handbook of Language Contact, 618-633. Malden, Mass.: Wiley-Blackwell. DoI: 10.1002/9781444318159.ch30.

Karanfilovski, Maksim. 2009. The Enidze Vardar dialect. Skopje: U кIM.

Kittilä, Seppo T. 2006. Object-, animacy- and role-based strategies: A typology of object marking. Studies in Language 30 (1): 1-32. DoI: 10.1075/sl.30.1.02kit.

Kittilä, Seppo T. 2011. Formal and Functional Differences between Differential Object Marking and Differential R Marking: Unity or Disunity? Open Journal of Modern Linguistics 1(1): 1-8. DOI: 10.4236/ojml.2011.11001.

Koneski, Blaže. 1967. Istorija na makedonskiot jazik. Skopje: Kultura.

Koneski, Blaže. 1986. Makedonskiot XIX vek, jazični i kniževno-istoriski prilozi. Skopje: Kultura.

Labroska, Veselinka. 2003. Govorot na seloto Kula - Sersko. Skopje: IMJ.

Leonetti, Manuel. 2004. Specificity and object marking: the case of Spanish. Catalan Journal of Linguistics 3: 75-114.

Lindstedt, Jouko. 200o. Linguistic Balkanization: Contact-induced change by mutual reinforcement. In Dicky Gilbers, John Nerbonne and Jos Schaeken (eds.), Languages 
in Contact (Studies in Slavic and General Linguistics 28), 231-246. Amsterdam/ Atlanta, GA: Rodopi.

Lindstedt, Jouko. 2014. Balkan Slavic and Balkan Romance: From congruence to convergence. In Juliane Besters-Dilger, Cynthia Dermarkar, Stefan Pfänder, and Achim Rabus (eds.), Congruence in Contact-induced Language Change: Language Families, Typological Resemblance, and Perceived Similarity, 168-183. Berlin/Boston: De Gruyter. Dor: 10.1515/9783110338454.168.

Lindstedt, Jouko. 2015. Sintaksata na Konikovskoto evangelie - dijalektna ili kalkirana? XLI meǵunarodna naučna konferencija na XLVII Meǵunaroden seminar za makedonskijazik, literatura i kultura, 77-84. Skopje: UKIM.

Lindstedt, Jouko. 2019. Diachronic regularities explaining the tendency towards explicit analytic marking in Balkan syntax. In Brian Joseph and Iliana Krapova (eds.), Balkan syntax and (universal) principles of grammar, 70-94. Berlin/New York: Mouton De Gruyter.

Lindstedt, Jouko, Ljudmil Spasov, and Juhani Nuorluoto (eds.). 2008. The Konikovo Gospel/Konikovsko evangelie: Bibl. Patr. Alex. 268. Helsinki: Societas Scientiarum Fennica.

Mackridge, Peter. 2009. Language and National Identity in Greece, 1766-1976. Oxford: Oxford University Press.

Malchukov, Andrej L. 2008. Animacy and asymmetries in differential case marking. Lingua 118: 203-221. DOI: 10.1016/j.lingua.2007.02.005.

Markovik, Marjan. 2007. Aromanskiot imakedonskiot govor od ohridsko-struškiot region vo balkanski kontekst. Skopje: MANU.

Matras, Yaron. 2007. The borrowability of structural categories. In Yaron Matras and Jeannette Sakel (eds.), Grammatical borrowing in cross-linguistic survey, 31-73. Berlin/New York: Mouton de Gruyter. Dor: 10.1515/9783110199192.31.

Matras, Yaron. 2009. Language Contact. Cambridge: Cambridge University Press. DoI: 10.1017/CBO9780511809873.

Matras, Yaron and Jeannette Sakel. 2007. Investigating the mechanisms of pattern replication in language convergence. Studies in Language 31 (4): 829-865. DoI: 10.1075/ sl.31.4.05mat.

Mazón, André and André Vaillant. 1938. L'Évangéliaire de Kulakia. Un parle se slave du Bas-Vardar. Paris: Librairie de Droz. Downloadable at http://damj.manu.edu.mk/ pdf/oo10\%2oKulakia.pdf (accessed June 24, 2016).

Mladenov, Maksim. 1993. Bălgarskite govori v Rumănija. Sofia: BANU.

Næss, Åshild. 2004. What markedness marks: the markedness problem with direct objects. Lingua 114 (9-10): 1186-1212. DoI: 10.1016/j.lingua.2003.07.005.

Nichev, Aleksandăr. 1997. Chetiriezichnijat rechnik na Daniil. Sofia: BANU.

Peev, Kosta. 1987. Kukuškiot govor. Skopje: Studentski zbor. 
Penušliski, Kiril (ed.). 1985. Stefan Verkovik, South Macedonian folk tales (4). Skopje: Makedonska kniga.

Seliščev, Afanasij M. [1918] 1981. Ocherki po makedonskoy dialektologii. Sofia: Nauka i izkustvo.

Siewierska, Anna and Dik Bakker. 2008. Case and Alternative Strategies: Word Order and Agreement Marking. In Andrej Malchukov and Andrew Spencer (eds.), The $O x$ ford Handbook of Case, 290-303. Oxford: Oxford University Press. DoI: 10.1093/ oxfordhb/9780199206476.013.0020.

Sobolev, Andrej N. 2008. On some Aromanian grammatical patterns in the Balkan Slavonic dialects. In Biljana Sikimić and Tijana Ašić (eds.), The Romance Balkans, 113-121. Belgrade: SANU, Institute for Balkan Studies.

de Swart, Peter. 2007. Cross-linguistic Variation in Object Marking. PhD dissertation, Radboud University, Nijmegen.

de Swart, Peter and Helen de Hoop. 2007. Semantic aspects of deferential object marking. In Estella Puig-Waldmüller (ed.), Proceedings of Sinn und Bedeuntung 11, 598611. Barcelona: Universitat Pompeu Fabra.

Topolinjska, Zuzana. 1995. Makedonskite dijalekti vo Egejska Makedonija (1). Skopje: MANU.

Topolińska, Zuzanna. 1995. Convergent Evolution, Creolization and Referentiality. In Eva Hajičová, Miroslav Červenka, Oldřich Leška, and Petr Sgall (eds.), Prague Linguistic Circle Papers, 239-247. Amsterdam:John Benjamins. DoI:10.1075/plcp.1.21top. Topolińska, Zuzanna. 2010. The Balkan Sprachbund from a Slavic perspective. Zbornik Matice srpske za filologiju i lingvistiku 53 (1): 33-6o.

Tošev, Krum. 1970. Nekoi inovacii vo gradskiot struški govor. Prilozi 1 (1):105-113. Skopje: MANU.

Vidoeski, Božidar. 1998. Dijalektite na makedonskiot jazik (1). Skopje: MANU.

Vidoeski, Božidar. 1999. Dijalektite na makedonskiot jazik (2). Skopje: MANU.

Vidoeski, Božidar. 2000. Tekstovi od dijalektite na makedonskiot jazik. Skopje: IMJ.

Witzlack-Makarevich, Alena and Ilja A. Seržant. 2018. Differential argument marking: Patterns of variation. In Ilja A. Seržant and Alena Witzlack-Makarevich (eds.), Diachrony of differential argument marking, 1-40. Berlin: Language Science Press. Dor: 10.5281/zenodo.1228243. 